\title{
Liability for Aviation Crimes: Criminal Law and Criminological Aspects
}

\author{
Sofiia Lykhova 1 [0000-0003-4755-7474], Dariia Hurina 2 [0000-0002-4613-8561], \\ Viktoriia Sysoieva *1 [0000-0003-1673-3682] \\ ${ }^{1}$ National Aviation University, Kyiv, Ukraine \\ ${ }^{2}$ State Scientific Research Forensic Centre of the Ministry of Internal Affairs of Ukraine, Kyiv, Ukraine \\ *k_kppip@ukr.net
}

\begin{abstract}
The article considers the theoretical and practical aspects of the application of criminal liability for crimes in the field of aviation. The study of criminal liability for crimes in the field of aviation involves the use of historical, systematic, integrated approaches. The forensic practice of such crimes is analyzed. Judgments from recent criminal proceedings in aviation crimes have been selected for the study. It is noted that the most common crimes are committed by persons who are not employees of air transport. The composition of such crimes involves the commission of acts that are prohibited by air traffic regulations, or consist in non-compliance with those instructions that a person could and should have complied with (for example, refusal to use seat belts). In conclusion, it is noted that criminal offenses in the field of aviation today are not widespread in Ukraine. There is an assumption about the high probability of latency of these types of criminal offenses.
\end{abstract}

Keywords: aviation, safety, crime, offense, danger.

\section{INTRODUCTION}

Ensuring peace and security of mankind as one of the main tasks of the Criminal Code of Ukraine is of global and strategic importance. Security is one of the most important needs, after physiological, namely - the need for food, clothing, housing.

In this regard, O. Kirichenko rightly notes that security as one of the most controversial and complex social phenomena has long been the object of careful research interest of representatives of various branches of humanities and natural sciences - historians, philosophers, political scientists, sociologists, jurists, culturologists, psychologists, economists, mathematicians chemists, nuclear scientists, etc. However, in Soviet times, the problems of philosophical, sociological and legal foundations of the concept of security were not comprehensively developed. Security in the philosophical sense has a pronounced anthropocentric nature, it is closed to the person and is one of the most important conditions for life and the realization of its essential forces - vital, social, spiritual [1]. In its content, security presupposes, on the one hand, the absence of danger, and on the other - the presence of a state of protection of vital interests of the individual, society, state from internal and external threats, encroachments and dangers.

According to the preamble of the Air Code of Ukraine [2], state regulation of aviation and use of Ukrainian airspace is aimed at ensuring aviation safety, ensuring the interests of the state, national security and the needs of society and economy in air transportation and aviation. This means that the state sets certain rules and restrictions to ensure security as one of the most important needs.

Criminal law protection of public relations in the field of aviation is designed to ensure the necessary state of protection of vital interests of the individual, society, state from internal and external threats, encroachments and dangers.

The purpose of the article is to study and comprehensive criminal law and criminological analysis $[3,4]$ of the application of criminal liability to persons who commit crimes in the field of aviation.

\section{MATERIALS AND METHODS}

The methodology of research of criminal liability for crimes in the field of aviation involves the study of the scientific basis, a set of methods, techniques, tools 
needed to determine the characteristics of these crimes. The methodology covers a number of organizational, methodological, regulatory factors that will be discussed. The methodology should be considered as a certain unity, a system of scientific theories, principles and rules for the palette of scientific research. It is quite rich, elegant and complex formation, contains a range of procedures and operations that can help to reveal the content and essence of the studied processes and phenomena. It is important that the research methodology is mediated by the methods, techniques, techniques and areas of understanding the results of the study. The methodology primarily affects the conceptual understanding of the research program. Practice shows that in the absence of a perfect methodology it is very difficult to predict those aspects that will be studied from the standpoint of research management [5]. The methodological principles that are the basis for the study of criminal liability for crimes in the field of aviation are contained in the following: a) the attitude to reality as an objective reality; b) the need to distinguish the essential elements from the secondary (in the study of objective reality); c) constancy and variability of elements (which constitute the system under study); d) the historicity of the phenomena and processes being studied; e) the importance of conflicts in the development of the phenomenon under study; g) specificity, objectivity, etc. [6]. The study of criminal liability for crimes in the field of aviation involves the use of historical, systematic, integrated approaches. The historical approach as an important manifestation of the dialectical study of society considers this crime as a kind of system that operates in different historical conditions, shows its changes at different stages of social development. A systems approach allows you to consider certain processes in the relationship and interaction. An integrated approach ensures the unity and continuity of system elements. Methodological principles (approaches, techniques, methods) of scientific knowledge are diverse. The relevant philosophical literature speaks of the multiplicity and diversity of methodologies. The methodology of research of criminal liability for crimes in the field of aviation is a conceptual statement of the purpose, content, methods, principles, research methods that provide the most objective, accurate, systematic information on comprehensive activities to prevent these crimes. It identifies ways to acquire scientific knowledge, provides a way to achieve the research goal and creates a system of information about crimes in the field of aviation.

The empirical basis of the study of criminal liability is the information of the Unified Register of Judgments, namely the verdicts of courts in cases of crimes in the field of aviation.

\section{RESULTS}

Criminal protection in the field of aviation is one of the components of ensuring peace and security of mankind. Regarding the outlined issues, it should be noted that the Air Code of Ukraine defines aviation security as protection of civil aviation from acts of illegal interference, which is provided by a set of measures involving human and material resources [2]. The main regulations aimed at ensuring aviation security operate at three levels:

1) global level (International Civil Aviation Organization (ICAO), main documents: Convention on Crimes and Certain Other Acts Committed on Board Aircraft (Tokyo, 1963), Convention on the Suppression of Unlawful Seizure of Aircraft (The Hague, 1971) Convention for the Suppression of Unlawful Acts against the Safety of Civil Aviation (Montreal, 1971), the Protocol for the Suppression of Acts of Violence at Airports Serving Civil Aviation (Montreal, 1988), supplements the 1971 Montreal Convention. Convention on the Marking of Plastic Explosives for the Purpose of Detection (Montreal, 1991), Convention on the Suppression of Unlawful Acts in Respect of International Civil Aviation (Beijing, 2010);

2) regional level (European Aviation Safety Agency (EASA), European Civil Aviation Conference (ECAC), ICAO European and North Atlantic Bureau (Paris), main documents - Policy of the European Civil Aviation Conference in the field of aviation security;

3) national level - State Aviation Administration (SAA), main documents: Air Code of Ukraine of 19.05.2011, Law of Ukraine "On the State Program of Aviation Security of Civil Aviation" of 20.02.2003, Order of the Ministry of Transport and Communications of Ukraine № 390 dated 11.05.2007, Instruction on assessment of the level of threat to the safety of civil aviation of Ukraine [7].

Speaking of crimes in the field of aviation, it should be noted that the current Criminal Code of Ukraine contains a wide list of such crimes. However, forensic $[8,9]$ practice shows that the vast majority of such crimes are almost non-existent in practice. Only a few articles of the Criminal Code of Ukraine on liability for crimes in the field of aviation are applied in practice. Thus, violation of air flight rules (Article 281 of the Criminal Code of Ukraine) is currently one of the most common crimes in the field of aviation. The composition of this crime involves the commission of actions that are prohibited by the rules of air flight, or failure to comply with the instructions that a person could and should have complied with (refusal to use seat belts, etc.). Aircraft safety rules should be understood as regulations governing the flight of aircraft, as well as instructions from the commander and crew members of the aircraft, which follow from them and are mandatory for persons on board the aircraft during the flight. The flight is the time from the moment of closing the door before the start of the flight and until the moment of allowing passengers to leave the aircraft after arrival. Violation of flight rules 
may consist of violation of piloting rules (evasion of the assigned flight level, violation of established norms and schemes of altitude gain, exit from the aerodrome area, descent or approach), conducting various air operations (landing, bombing, construction of engineering structures by helicopters, etc.) or other flight rules (taking on board a ship the number of passengers that exceeds the established standards, flight with radio off, unauthorized light or other electromagnetic radiation, flight without permission in restricted areas, transfer of control of the aircraft to a third party, flight according to the rules of visual flights in the mountains at night), etc. [10]. It should be noted that the Unified Register of Court Decisions today does not contain court decisions on such crimes.

For example, according to the verdict in case № $527 / 1850 / 18$, in June 2018, citizen A., not having a pilot's license and not being an air transport employee, on an amateur aircraft (such as a hang glider, according to the Aviation Rules of Ukraine), who is not registered in the State Register of Civil Aircraft of Ukraine and does not have the necessary permits to fly, in order to perform agrochemical works, flew over fields located within the village of Zhuky, Globinsky district of Poltava region. These actions, according to the findings of the State Aviation Service of Ukraine, created a danger to human life or the occurrence of other serious consequences.

The actions of citizen A. are qualified under Part 1 of Art. 281 of the Criminal code of Ukraine - as violation of rules of safety of flights of aircraft by the persons who are not workers of air transport if it created danger to life of people or occurrence of other serious consequences.

It should be added that simultaneously with the indictment against citizen A., the prosecutor sent to the court a plea agreement concluded in September 2018 during the pre-trial investigation between the prosecutor of the Globinsky department and the suspected citizen A. According to the agreement, the accused citizen A. fully admits his guilt in committing a crime under Part 1 of Art. 281 of the Criminal code of Ukraine, doesn't deny the circumstances of commission of the crime incriminated to it which are stated in the message on suspicion, unconditionally admits accusation in volume of suspicion [11]. Thus, in accordance with the plea agreement, citizen A. was sentenced to a fine in the form of a crime.

Violation of the rules of preparation for flights is poor quality or unscheduled repair and maintenance of aircraft, i.e. repair (maintenance) with a deviation from the standards, norms and rules that determine the technology of their conduct (for example, leaving those defects that needed to be eliminated, installation of damaged parts). Violation of these rules is the release of the aircraft into flight with incomplete maintenance, refueling with substandard fuel or special fluids, disregard for the state of resources and service life of the aircraft and its components, admission to the flight in violation of pre-flight rest or working hours, medical requirements inspection, or substandard repair and maintenance of aerodromes, signaling, communication, etc. It is a violation of the rules of operation of aircraft to operate a defective aircraft or those that are not registered and do not have a certificate of airworthiness (or a special certificate of airworthiness issued for the flight to the place of repair after damage that caused partial loss of fitness). before flights), misuse of aircraft, improper placement of cargo on board the aircraft, etc. Fully covered by Art. 416 of the Criminal Code of Ukraine and does not require additional qualifications under Part 2 of Art. 269 of the Criminal code of Ukraine illegal transportation on the aircraft of explosives or flammable substances that caused heavy consequences if it is made by the member of crew of the plane. However, the responsibility for these actions in the absence of such consequences, including for crew members, occurs under Part 1 of Art. 269 of the Criminal Code of Ukraine. In case of violation of non-flight rules, as well as safety rules when performing work to improve the safety of danger performed in construction with the help of helicopters, the guilty person is not liable under Art. 272 of the Criminal code of Ukraine. If the rules of flight are violated by the military crew of the aircraft consisted of entry into Ukraine, freedom from Ukraine without proper permission, as well as unauthorized routes specified in the permits, landing sites, routes, corridors or echelons and the consequences provided for in Art. 416 of the Criminal Code of Ukraine, they qualify for this state. [10]. Analyzing the judicial and investigative practice, we can conclude that such ways of committing crimes have not been committed in recent years. As a rule, crimes in the field of aviation are presented in the Unified Register of Judgments as those committed by persons who are not employees of air transport.

For example, in July 2017, citizen B., not being an air transport employee, purchased an aircraft without registration of ownership. Prior to the flight, citizen B. did not receive permission from the State Aviation Service of Ukraine to perform flights, flight documentation, which is determined by the aviation rules of Ukraine, did not undergo the training required to fly, did not receive a certificate of aviation personnel, did not approve flights by communication with air traffic services and did not insure in the manner prescribed by law liability for possible damage caused to third parties. In addition, citizen $\mathrm{B}$. independently, without a certificate of aircraft maintenance personnel, performed pre-flight training of the aircraft.

After that, citizen B. without receiving the above approval documents, grossly violating the requirements of the Rules of Aircraft Flight and Air Traffic Services in the airspace of Ukraine, placed four passengers in the aircraft instead of three, as provided by the Flight Manual. Then, for amusement purposes, citizen B. made 
an unauthorized departure on the said unprepared aircraft from the Kolomyia runway, which is located $2.9 \mathrm{~km}$ from the city of Kolomyia in the Ivano-Frankivsk region. During the flight in the area of the runway in Kolomyia and the village Kornych, Kolomyia district, IvanoFrankivsk region, due to a technical malfunction of the engine, citizen B. made a forced landing on the territory of a pasture near the village of Corniche. During the landing, while the wheels were running on the grass, the front rack of the chassis entered the ditch, as a result of which the aircraft overturned. As a result of the forced landing and subsequent overturning, the aircraft suffered significant damage to the structure, and the passengers were injured. Thus, the forced landing and overturning of the aircraft was caused by citizen B., who violated the requirements of the current legislation of Ukraine.

Violation of these safety rules, which resulted in the forced landing and overturning of the aircraft, caused injuries to passengers in the form of abdominal injuries, with damage to internal organs, accompanied by internal bleeding, which are serious injuries as life-threatening. The forced landing and overturning of the aircraft occurred due to the pilot of citizen B., who violated the requirements of current legislation of Ukraine [12].

In general, violation of flight rules, preparation for them and operation of aircraft involves violation of the established procedure for organization, execution and provision of flights, supervision, flight safety control and flight safety. Rules of flights and preparation for them, operation of aircraft are established in acts of international domestic law, in particular, in acts of the Committee on the Use of Airspace of Ukraine, advisers on aviation engineering and navigational service. If the violation of the rules of flight of military aircraft was combined with the violation of the rules of international flights, then for intentionally illegal entry into Ukraine or departure from Ukraine, the crew of a military aircraft are liable under Art. 334 of the Criminal Code of Ukraine [13], and for other violations of the rules of international flights, which did not cause the consequences provided for in Art. 416 of the Criminal Code of Ukraine [10].

\section{DISCUSSION}

The study of empirical material shows that currently the vast majority of registered and investigated crimes in the field of aviation are examples of gross violations of air flight rules (Article 281 of the Criminal Code of Ukraine). Unfortunately, the official statistical reports on registered criminal offenses (information from the Office of the Prosecutor General) do not contain separate information on registered crimes in the field of aviation. Therefore, we can talk about their quantitative and qualitative indicators only on the basis of doctrinal sources and information from the Unified Register of Judgments.
According to the above sources, such crimes are quite uncommon. Over the last 5 years, no more than 10 sentences in cases of violation of air traffic rules have been registered in the Unified Register of Judgments. On the one hand, we can talk about good and correct crime rates. In our country, a small number of crimes are committed in the field of aviation, and this is a positive assessment. However, on the other hand, it should be noted that the sentences registered in the above system indicate that the perpetrators have access to control of the aircraft, the presence of the actual aircraft in the property [14-16]. Given the cost of such modern technical units and regulatory requirements for the formalization of ownership, we can conclude that the opportunity to commit crimes of violation of air traffic rules have only wealthy people. Only a few sections of the population can afford to use small civil aviation in their daily lives. Only a few sections of the population can afford to use small civil aviation in their daily lives. Unfortunately, given the above factors, we can talk about the latency of these crimes. First, there is corruption, which is widespread in all spheres and spheres of public life. Second, law enforcement agencies do not always have the strategic and tactical ability to detect and register such a specific criminal offense. However, to date, neither law enforcement nor research institutions have been able to establish the impact of these factors on aviation crime.

\section{CONCLUSIONS}

Summing up, it should be noted that crimes in the field of aviation are not widespread in Ukraine today. Aviation security issues are researched and addressed at three levels: global, regional and national. Among the corpus delict in forensic practice, the most common cases of violation of air traffic rules. The analyzed verdicts of criminal proceedings show that, as a rule, guilty persons neglect safety rules. According to the disposition of Article 281 of the Criminal Code of Ukraine, in order to qualify the above-mentioned act as criminally illegal, it is necessary to create a danger to human life or the occurrence of other serious consequences. Perhaps such evaluative concepts are one of the reasons for the small number of court verdicts under this article of the Criminal Code of Ukraine. However, it is necessary to take into account the fact that today there are grounds to speak about the existing latency of these criminal offenses.

\section{REFERENCES}

[1] Kyrychenko, O.V. (2013), “Theoretical approaches to defining the category "security",", Scientific Bulletin of Dnipropetrovsk State University of Internal Affairs, vol. 2, pp. 368-375.

[2] Air Code of Ukraine, available at: https://zakon.rada.gov.ua/laws/show/339317\#Text 
[3] Korystin, Oleksandr and Svyrydiuk, Nataliia (2021), "Activities of Illegal Weapons Criminal Component of Hybrid Threats", Proceedings of the International Conference on Economics, Law and Education Research (ELER 2021), vol. 170, 22 March, pp. 86-91, DOI: 10.2991/aebmr.k.210320.016

[4] Korystin, Oleksandr and Svyrydiuk, Nataliia (2020), "Methodological principles of risk assessment in law enforcement activity", Nauka $i$ Pravookhorona, vol. 3 (49), pp. 191-198, DOI: $10.36486 / \mathrm{np} .2020 .3(49) .19$

[5] Kagdyba, A.M. (2008), "Methodological principles of research management", Agroincom, vol. 1-2, pp. 88-91.

[6] Avanesov, G.A. (1972), Theory and methodology of criminological forecasting, legal literature, Moscow, Rossija.

[7] Lykhova, S.Y. and Kochneva, A.O. (2014), "Criminal responsibility for theft or seizure Aircraft (article 278 of the Criminal Code of Ukraine)", Law Journal “Air and Space Law”, vol. 3 (32), pp. 135139.

[8] Omi Akter, Arnisha Akther, Md Ashraf Uddin and Md Manowarul Islam (2020), "Cloud Forensics: Challenges and Blockchain Based Solutions", International Journal of Wireless and Microwave
Technologies, vol. 10, no. 5, pp. 1-12, DOI: $10.5815 /$ ijwmt.2020.05.01

[9] Erhan, Akbal and Sengul, Dogan (2018), "Forensics Image Acquisition Process of Digital Evidence”, International Journal of Computer Network and Information Security, vol. 10, no. 5, pp. 1-8, DOI: $10.5815 / \mathrm{ijcnis.2018.05.01}$

[10] Lykhova, S.Y. and Nechyporuk, M.Y. (2015), "Criminal liability for violation of flight rules Legal Science and Practice: Challenges of Time": Proceedings of the V International Scientific and Practical Conference, pp. 68-70.

[11] Unified register of court decisions, available at: http://reyestr.court.gov.ua/Review/76819700

[12] Unified register of court decisions, available at: http://reyestr.court.gov.ua/Review/78537624

[13] Criminal Code of Ukraine, available at: https://zakon.rada.gov.ua/laws/show/234114\#Text

[14] Unified register of court decisions, available at: http://reyestr.court.gov.ua/Review/67254794

[15] Unified register of court decisions, available at: http://reyestr.court.gov.ua/Review/71247724

[16] Unified register of court decisions, available at: http://reyestr.court.gov.ua/Review/38484535 